\title{
İlköğretim Matematik Öğretmeni Adaylarının Etkinlik Uygulama Süreçlerinin İncelenmesi*
}

\section{A Study on the Processes of Activity Implementation by Prospective Primary Mathematics Teachers}

Ferhat Öztürk, ${ }^{\mathrm{a}, * *}$ Ahmet Işık ${ }^{\mathrm{b}}$

a Dr. Öğr. Üyesi, Kırıkkale Üniversitesi, Eğitim Fakültesi, Matematik ve Fen Bilimleri Eğitimi Bölümü, 71450, Kırıkkale/Türkiye. ORCID: 0000-0003-2849-8325

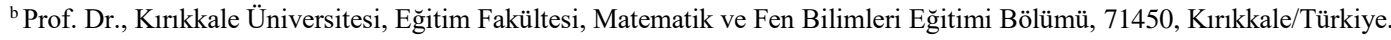
ORCID: 0000-0002-1599-2570

\section{MAKALE BİLGİSİ}

Makale Geçmişi:

Başvuru tarihi: 01 Eylül 2019

Düzeltme tarihi: 02 Aralık 2019

Kabul tarihi: 18 Aralık 2019

\section{Anahtar Kelimeler:}

Etkinlik

Etkinlik Uygulama

İlköğretim Matematik Öğretmeni Adayları

\section{A R T I CLE INFO}

\section{Article history:}

Received 01 September 2019

Received in revised form 02 December 2019

Accepted 18 December 2019

\section{Keywords:}

Activity

Activity Implementation

Prospective Primary Mathematics Teachers
ÖZ

$\mathrm{Bu}$ araştırmanın amacı; ilköğretim matematik öğretmeni adaylarının lisans eğitimleri doğrultusunda etkinlik uygulama süreçlerini incelemektir. Araştırmada nitel araştırma yaklaşımlarından durum çalışması yöntemi kullanılmıştır. Araştırmanın çalışma grubunu, Atatürk Üniversitesi Kazım Karabekir Eğitim Fakültesi İlköğretim Matematik Öğretmenliği Lisans Programı'nın dördüncü sınıfında öğrenim gören 12 öğretmen adayı oluşturmaktadır. Araştırma grubu belirlenirken araştırmaya uygun, verimli ve rahat ulaşılabilir bir örneklem seçildiği için kolay ulaşılabilir durum örneklemesi kullanılmıştır. Veri toplama aracı olarak, öğretmen adaylarının etkinlik uygulama süreçlerini incelemeye yönelik yarı yapılandırılmış görüşme formu hazırlanmıştır. $\mathrm{Bu}$ doğrultuda veriler, görüşme ve gözlem (video kaydı) yoluyla elde edilmiştir. Görüşmelerden elde edilen verilerin analizinde içerik analizi yöntemi kullanılmıştır. Araştırmadan elde edilen verilerin analizi sonucunda, ilköğretim matematik öğretmeni adaylarının etkinlik uygulama sürecine yönelik yeterli bilgi ve deneyime sahip olmadıkları tespit edilmiştir.

\section{A B S TR ACT}

The aim of this research is to investigate the processes of activity implementation of prospective primary mathematics teachers in the direction of undergraduate education. The case study design among qualitative methods was followed in this study. The participants were 12 prospective primary mathematics teachers who were fourth graders in the Department of Mathematics Teacher Training at Atatürk University. For sampling, convenience sampling was used by caring accessibility. As a data collection tool, a semi-structured interview form was prepared to investigate the processes of activity implementation of prospective teachers. Accordingly, the data were obtained through interview and observation (video recording). Content analysis was used as a qualitative research analysis technique for the data gathered through interviews. The findings of the study was seen that prospective primary mathematics teachers did not have experience and literateness about the processes of activity implementation.

\section{Giriş}

Öğrenme ve öğretme sürecine yönelik geleneksel yaklaşımlarla yeni yaklaşımlar arasındaki en köklü ayrışımı etkinlik kavramı oluşturmaktadır (Aykaç, 2007). Öğrenci merkezli olan bu yeni yaklaşımlar; bilgi ve becerilerin, öğrencilerin aktif olarak yapacakları etkinliklerle kazanılabileceğini savunur (Duru ve Korkmaz, 2010; Mishra ve Yadav, 2013; Yeniterzi, 2009). Benzer bir düşünceyle Doyle (1983) öğrencilerin öğrendiklerinin kendilerine yaptırılan etkinliklerle belirlendiğini ifade

\footnotetext{
* Bu çalışma birinci yazarın 2016 yılında Prof. Dr. Ahmet Işık danışmanlığında Atatürk Üniversitesi Eğitim Bilimleri Enstitüsü Matematik ve Fen Bilimleri Eğitimi Anabilim Dalı'nda yürüttüğü “İlköğretim Matematik Öğretmeni Adaylarının Etkinlik Hazırlama ve Uygulama Süreçlerinin İncelenmesi” başlıklı doktora tezinden türetilmiş ve 18-22 Nisan 2018 tarihinde Antalya'da düzenlenen 27. Uluslararası Eğitim Bilimleri Kongresi’nde sözlü bildiri olarak sunulmuştur.

${ }^{* *}$ Sorumlu yazar/Corresponding author.

e-posta: ferhatozturk@kku.edu.tr
} 
ederken, Christiansen ve Walter (1986) etkinliklerin öğrenme ve öğretme arasındaki etkileşimin temelini oluşturduğunu belirtmişlerdir. Bazı araştırmacılar ise etkinliklerin; öğrenme ortamlarında öğrencilerin öğrenmelerinin temelini oluşturan en önemli öğrenme birimi olduğunu (Doyle, 1988) ve öğrencilerin öğrenmelerini büyük ölçüde etkilediğini (Grevholm, Milman ve Clarke, 2009) ayrıca öğrenme-öğretme sürecinde ve öğrenme ürünlerinde olumlu etkiye neden olduğunu (Choo, 2007; Tzur, 2002) dile getirmişlerdir. Yine etkinliklerin önemine değinen Kilpatrick, Swafford ve Findell (2001) öğretimin kalitesinin, öğretmenler tarafından seçilen ve bilişsel olarak zor olan etkinliklerin sınıf ortamında uygulanmasına ve öğrencilerin bu etkinlikler üzerinde çalışarak öğrenmelerinin sağlanmasına bağlı olduğunu ifade etmişlerdir. Ayrıca Stein, Smith, Henningsen ve Silver (2009) öğrenme ve öğretme sürecinin merkezinde yer alan etkinliklerin, öğrenme ortamının niteliğini ve öğrencilerin kavramsal öğrenme düzeylerini belirlemede önemli bir rol oynadığını ifade etmektedir. Öte yandan matematiksel etkinliklerin matematiğin öğrenimi ve

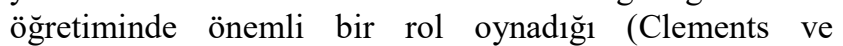
McMillan, 1996; Elbers, 2003; Gürbüz ve Toprak, 2014; Henningsen ve Stein, 1997; Herbst, 2008; Hiebert ve Wearne, 1993; Horoks ve Robert, 2007; Jones ve Pratt, 2006; Moyer ve Jones, 2004; Özden, 2009; Stein, Grover ve Henningsen, 1996; Tatsis, Kafoussi ve Skoumpourdi, 2008; Tzur, Zaslavsky ve Sullivan, 2008) birçok çalışmada ifade edilmiştir.

Diğer taraftan öğrenci merkezli olarak hazırlanan Ortaokul Matematik Dersi Öğretim Programı'nda (MEB, 2009) öğrencilere; öğrenme sürecine zihinsel ve fiziksel olarak aktif katılma, öğrenmelerinden sorumlu olma, kendilerini ifade etme, soru sorma, sorgulama-düşünme-tartışma, problem çözme, birlikte çalışma ve değerlendirme gibi, öğrenme ve öğretme sürecinde etkinliklerin kullanılması gerektiğine işaret eden roller verilmiştir. Programda öğrencilere verilen bu rollerin yanı sıra öğretmenlerin de yönlendirme, rehberlik yapma ve motive etme, sorgulama, soru sordurma, düşündürme ve tartıştırma, öğrenmeöğretme ortamını düzenleme ve etkinlik geliştirme ve uygulama gibi sahip olmaları gereken bazı özellikler ifade edilmiştir. Görüldüğü gibi programda öğrencilerin öğrenme ve öğretme sürecinin merkezine alınmış olması öğretmenlerin sorumluluklarını azaltmanın aksine onlara daha fazla sorumluluklar yüklemektedir. Bu bağlamda, Baki ve Hacısalihoğlu-Karadeniz'in (2013) bir öğretim programının başarıya ulaşmasında programı uygulayacak olan öğretmenlerin büyük pay sahibi olduğunu belirtmeleri ve ayrıca Aydoğdu-İskenderoğlu ve Baki'nin (2011) öğretmenlerin matematik öğretiminin en önemli arac1 olduğunu vurgulamaları bu görüşü desteklemektedir. Diğer taraftan ulusal ve uluslararası literatür incelendiğinde öğretmenlerin etkinlik uygulama süreçlerinde çeşitli sebeplerden dolayı problem yaşadıklarını ortaya koyan birçok araştırma (Bal, 2008; Duru ve Korkmaz, 2010; Hsu, 2013; Shakirova, Falileeva ve Kinder, 2016; Sullivan, Clarke, Clarke ve O'Shea, 2010; Toptaş, 2008) mevcuttur. Etkinlik uygulama sürecinin etkili bir şekilde gerçekleşebilmesinin, etkinlik kavramının öğretmenler tarafından nasıl algılandığıyla doğrudan ilgili olduğu (Uğurel ve Bukova-Güzel, 2010), etkinlik uygulama sürecinin öğretmenin pedagojik bilgisiyle şekillendiği ve bu durumun da öğrenme ve öğretme sürecini olumlu ya da olumsuz olarak etkilediği (Horoks ve Robert, 2007; Stein ve Smith, 1998; Sullivan ve diğerleri, 2010; Swan, 2008) söylenebilir. Horoks ve Robert (2007) çalışmalarında, etkinlik kullanımıyla ilgili yeterli bilgiye sahip olmayan öğretmenlerin etkinlik uygulama sürecinde yaşadıkları problemlerden kurtulmak için etkinlik uygulama sürecini gözden geçirmek yerine kullandıkları etkinliklerden vazgeçtiklerini ifade etmişlerdir.

Etkinliklerin uygulanmasında öğretmenlerin önemli bir role sahip olduğu (Kerpiç, 2011; Özmantar, Bozkurt, Demir, Bingölbali ve Açıl, 2010) ve bu sebeple etkinliklerin uygulayıcıları olan ögrretmenlerle bir anlam bulduğu (Toprak, Uğurel ve Tuncer, 2014) söylenebilir. Bu nedenle akıl yürütme ve ilişkilendirme gibi üst düzey matematiksel süreç becerisi gerektiren etkinliklerin etkili bir şekilde uygulanabilmesi ve uygulama sürecinin nitelikli bir duruma gelmesi için öğretmenlerin yeterli bilgi ve donanıma sahip olmaları son derece önemlidir (Karakuş ve Yeşilpınar, 2013; Sullivan, Clarke ve Clarke, 2009). Ayrica matematik dersi öğretim programında yer alan amaç ve kazanımlar doğrultusunda etkinlik uygulama süreci, ileri seviyede matematik eğitimi alan bilgisi ve öğretim yöntem bilgisi gerektirir (Baki ve Hacısalihoğlu-Karadeniz, 2013). İşte bu sebeple nitelikli bir matematik öğretiminin gerçekleştirilebilmesi, nitelikli öğretmen eğitimi ile sağlanabilir (Uşun ve Gökçen, 2010). Hallinan ve Khmelkov'un (2001) ifade ettiği gibi eğitimdeki ilerlemenin anahtarı, öğretmen eğitimini geliştirmektir. Öte yandan öğretmen yetiştirme programlarının öğretmen eğitiminde etkili olmadıkları, güncel ihtiyaçlara cevap vermedikleri ve uygulamadan uzak oldukları, araştırmacıların eleştiri hedefi olmuştur (DarlingHammond, 2000). Dolayısıyla nitelikli bir matematik öğretimi için ilköğretim matematik öğretmeni adaylarının lisans öğrenimleri boyunca almış oldukları derslerin, adayların etkinlik uygulama becerilerini nasıl etkilediğinin ortaya çıkarılması önemlidir. Bu önemin yanı sıra ilgili literatür incelendiğinde matematik öğretmeni adaylarının etkinlik kavramiyla ilgili bilgi ve becerilerinin tespitine yönelik araştırmaların (Özgen ve Alkan, 2011; Özgen ve Alkan, 2014; Toprak, Uğurel ve Tuncer, 2014) yok denecek kadar az olduğu ve bu araştırmaların tamamının ortaöğretim matematik öğretmeni adaylarıyla yürütüldüğü ve bunların da sadece etkinlik hazırlama sürecine yönelik olduğu dikkate alındığında, bu konudaki araştırmaların azlığı göze çarpmaktadır. Bu bağlamda araştırmanın amacı, ilköğretim matematik öğretmeni adaylarının lisans öğrenimleri doğrultusunda etkinlik uygulama süreçlerini incelemektir. $\mathrm{Bu}$ amaç doğrultusunda yapılan bu araştırma nitelikli bir öğretmen eğitimi için lisans derslerinin etkinliklerinin arttırılmasında öğretmen eğitimcilerine fikir verebilir.

\section{Yöntem}

Bu bölümde; araştırma deseninden, çalışma grubundan, veri toplama aracından, verilerin analizinden ve uygulama sürecinden bahsedilmiştir.

\subsection{Araştırma Deseni}

$\mathrm{Bu}$ araştırmada; nitel araştırma yaklaşımlarından durum çalışması yöntemi kullanılmıştır. Nitel araştırma; sonuçtan daha çok sürece önem veren, detaylı ve derinlemesine araştırma imkânı sunan (Bogdan ve Biklen, 2007; Patton, 2002) ve görüşme, gözlem, doküman analizi gibi veri 
toplama araçlarının kullanıldığı bir araştırma yöntemi olarak tanımlanabilir. Durum çalışması ise, güncel bir olgunun kendi doğal ortamında derinlemesine araştırıldığı, olgu ve içerik arasındaki sınırların belirgin olmadığı durumlarda kullanılan ve birden fazla veri kaynağına ihtiyaç duyulan (Yin, 2003) bir nitel araştırma yöntemidir. Bu bağlamda araştırmada, ilköğretim matematik öğretmeni adaylarının lisans öğrenimleri doğrultusunda etkinlik uygulama süreçlerinin gerçekçi ve bütüncül bir yaklaşımla derinlemesine incelenmesi amaçlandığı için nitel araştırma yaklaşımlarından durum çalışması yöntemi kullanılmıştır.

\section{2. Çalışma Grubu}

$\mathrm{Bu}$ çalışmanın araştırma grubunu, Atatürk Üniversitesi Kazım Karabekir Eğitim Fakültesi İlköğretim Matematik Öğretmenliği Lisans Programı'nın dördüncü sınıfında, altısı birinci öğretim ve diğer altısı ikinci öğretimde öğrenim gören ve üçü erkek, dokuzu bayan olmak üzere toplam 12 öğretmen adayı oluşturmaktadır. Araştırma grubu belirlenirken araştırmaya uygun ve rahat ulaşılabilir bir örneklem seçildiği için kolay ulaşılabilir durum örneklemesi kullanılmıştır. Kolay ulaşılabilir durum örneklemesi; uygun, verimli ve rahat ulaşılabilir bir araştırma grubunun seçimini sağladığından (McMillan ve Schumacher, 2010) ve diğer örnekleme yöntemlerine kıyasla ekonomik, kolay ve hızlı olduğundan (Gürbüz ve Şahin, 2014) araştırmacılar tarafından yaygın olarak tercih edilir. Ayrıca araştırma grubu gönüllülük esasına göre belirlenerek araştırmaya katılan öğretmen adaylarına gönüllülük sözleşmesi imzalatılmış ve adayların isimlerinin yerine; örneğin, $\ddot{O}_{1}$ birinci öğretmen adayını, $\ddot{O}_{2}$ ikinci öğretmen adayını temsil etmek üzere $\ddot{O}_{1}, \ldots, \ddot{O}_{12}$ şeklinde kodlar kullanılmıştır.

\subsection{Veri Toplama Aracı}

Araştırmada veri toplama amacıyla yarı yapılandırılmış görüşme formu kullanılmış ve görüşme verilerinin teyit edilebilmesi için daha sonra incelenmek üzere gözlem amacıyla araştırmacılar tarafından öğretmenlik uygulaması dersi kapsamında her bir öğretmen adayının hazırlamış oldukları etkinlikleri kullanarak sunum yapacakları derslere ait video kaydı yapılmıştır. Görüşme formu hazırlanırken literatürden ve uzman görüşlerinden yararlanılmıştır. İlk aşamada taslak olarak hazırlanan bu formun geliştirilmesinde nitel araştırmalar konusunda yetkin; ikisi profesör, birisi doçent ve diğeri yardımcı doçent olmak üzere üçü matematik eğitimcisi ve diğeri kimya eğitimcisi olan dört uzmanın görüşüne başvurulmuştur. Uzmanlar tarafindan görüşme formunda yer alan bazı soruların yönlendirici ifadeler içerdiği ifade edildiği için bu soruların sayısında herhangi bir değişiklik yapılmadan sadece ifade şekli açısından yeniden düzenlenmesiyle birlikte pilot uygulama yapılmıştır. Pilot uygulama, asıl çalışma grubundaki öğretmen adayları dışında benzer niteliklere sahip farklı 12 öğretmen adayı ile yürütülmüştür. Pilot uygulamadan elde edilen bilgi ve tecrübeler sonucunda görüşme formu tekrar gözden geçirilmiş ve yine aynı dört uzmanın görüşüne başvurularak yeniden düzenlenmiştir. Sonuç olarak altı açık uçlu sorudan oluşan (bu sorulara bulgular bölümünde yer verilmiştir) yarı yapılandırılmış görüşme formu asıl araştırma için uygulanır hâle getirilmiştir.

\subsection{Verilerin Analizi}

Öğretmen adaylarının her biriyle, ayrı ayrı yapılan bütün görüşmeler adayların izinleri alınarak ses kayıt cihazı ile kaydedilmiştir. Yapılan bu ses kayıtları daha sonra analiz edilmek üzere tek tek dinlenerek yazılı metin hâline getirilmiştir. Bu metinlerin analizinde içerik analizi yöntemi kullanılmıştır. İçerik analizi; veri toplama ile başlayıp kategori ve kod çıkarımıyla son bulan, verilerin anlamlandırılması ve sentezlenmesi araştırmacılar tarafindan yapılan bir süreçtir (McMillan ve Schumacher, 2010). İçerik analizi ile görüşmelerden elde edilen metinler incelenerek öncelikle kodlar daha sonra eğer varsa benzer kodlar bir araya getirilerek kategoriler oluşturulmuştur. $\mathrm{Bu}$ kod ve kategori oluşturma işlemi, doğru ve güvenilir bulgular elde edebilmek amacıyla araştırmacılardan birisi ve araştırma sürecinin dişında bulunan bir akademisyenle birlikte farklı zamanlarda birkaç kez yinelenmiştir. Kod ve kategori oluşturma amacıyla yapılan ikili tartışmalar sonucunda üzerinde görüş birliğine varılan kod ve kategoriler tablolar halinde sunularak açıklanmaya çalışılmıştır.

Öğretmen adayları ile yapılan görüşme verilerinin teyit edilebilmesi için araştırmacılar tarafından her bir öğretmen adayının etkinliklerini uyguladıkları derslere ait video kaydı yapılmıştır. Video kayıtları daha sonra araştırmacılardan birisi tarafından farklı zaman dilimlerinde birkaç kez izlenerek adayların uygulama sürecinde matematiksel terim ve kavramların ifadelerinde yaptıkları hatalara yönelik cevaplar teyit edilmeye çalışılmıştır. Adayların ilgili video kayıtlarına ait bazı görseller görüşme verilerini desteklemek amacıyla bulgular kısmında sunulmuştur.

\subsection{Uygulama Süreci}

Araştırma sürecinde öncelikle deneyimli iki matematik öğretmeninin etkinlik uygulamaya uygun konu önerileriyle birlikte eğitim-öğretim sürecini aksatmayacak haftalar dikkate alınmış ve bu doğrultuda öğretmen adaylarının etkinlik kullanarak ders anlatacakları sınıf düzeyi, öğrenme alanı, alt öğrenme alanı ve kazanımlar belirlenmiştir. Sonrasında öğretmen adaylarıyla ilk toplantı gerçekleştirilip adaylara araştırma sürecinin işleyişi hakkında bilgi verilmiş ve adayların araştırmaya gönüllü olarak katıldıklarına dair gönüllülük sözleşmesi imzalatılmıştır.

Öğretmen adaylarıyla yapılan ikinci toplantıda, adaylara etkinlik kullanacakları sinıflara ait konular kura ile verilmiştir. Adaylara verilen sınıf düzeyi, öğrenme alanı ve alt öğrenme alanlarına dair bilgiler Tablo 1'de sunulmuştur.

Tablo 1. Uygulama için Adaylara Dağıtılan Konu Başlıkları

\begin{tabular}{cccc}
\hline $\begin{array}{c}\text { Öğretmen } \\
\text { Adayı }\end{array}$ & $\begin{array}{c}\text { Sınıf } \\
\text { Düzeyi }\end{array}$ & $\begin{array}{c}\text { Öğrenme } \\
\text { Alanı }\end{array}$ & Alt Öğrenme Alanı \\
\hline$\ddot{O ̈}_{1}$, Ö$_{2}$ & 6 & Ölçme & Sıvıları ölçme \\
\hline$\ddot{O}_{3}, \ddot{O}_{4}$ & 6 & Ölçme & Hacim ölçme \\
\hline$\ddot{O}_{5}, \ddot{O}_{6}$ & 7 & Geometri & Çember ve daire \\
\hline$\ddot{O ̈}_{7}, \ddot{O ̈}_{8}$ & 7 & Geometri & Çemberin ve parçasının uzunluğu \\
\hline$\ddot{O}_{9}, \ddot{O}_{10}$ & 8 & Ölçme & $\begin{array}{c}\text { Geometrik cisimlerin yüzey } \\
\text { alanları }\end{array}$ \\
\hline$\ddot{O}_{11}, \ddot{O}_{12}$ & 8 & Ölçme & Geometrik cisimlerin yüzey alanları \\
\hline
\end{tabular}

Adaylarla yapılan üçüncü toplantıda, adayların uygulamayı düşündükleri etkinlikler üzerinde konuşulmuştur. Öğretmen 
adaylarıyla gerçekleştirilen son toplantıda ise adayların uygulayacakları etkinliklerin planlarını içeren ders planları, plana bağlı ders anlatımının teyit edilebilmesi adına toplanarak etkinlik uygulama süreci sonrasında bu sürece dair adaylarla yapılacak olan görüşmeler için adayların uygun olduğu gün ve saat belirlenmiştir. Son olarak ise araştırma kapsamında daha sonra değerlendirilmek üzere adayların ders sunumlarına ait video kaydı yapılmış ve sonrasında öğretmen adaylarıyla belirlenen gün ve saatte etkinlik uygulama süreci ile ilgili görüşmeler yapılmıştır.

\section{Bulgular ve Yorumlar}

$\mathrm{Bu}$ kısımda öğretmen adayları ile yapılan görüşmelerden elde edilen bulgular ve bu bulguları desteklemek için video kayıtlarından elde edilen bazı görsel ögeler sunulmuştur.

Yapılan görüşmelerde adaylara ilk olarak "Etkinlik uygulama sürecinde ne gibi zorluklar yaşadınız ve bu zorlukları aşmak için neler yaptınız?" sorusu yöneltilmiş olup sorunun ilk kısmına ait bulgular Tablo 2'de, ikinci kısmına ait bulgular ise Tablo 3'te sunulmuştur.

Tablo 2. Adayların Uygulama Sürecinde Yaşadıkları Zorluklara Yönelik Görüşleri

\begin{tabular}{|c|c|c|}
\hline Kategori & Kod & Öğretmen Adayı \\
\hline \multirow{5}{*}{$\begin{array}{l}\text { Öğretmen } \\
\text { adayından } \\
\text { kaynaklanan } \\
\text { zorluklar }\end{array}$} & $\begin{array}{l}\text { Ders süresini } \\
\text { ayarlayamama }\end{array}$ & $\ddot{\mathrm{O}}_{3}, \ddot{\mathrm{O}}_{5}, \ddot{\mathrm{O}}_{6}, \ddot{\mathrm{O}}_{11}$ \\
\hline & $\begin{array}{l}\text { Sınıf hâkimiyetini } \\
\text { sağlayamama }\end{array}$ & $\ddot{\mathrm{O}}_{2}, \ddot{\mathrm{O}}_{9}, \ddot{\mathrm{O}}_{10}, \ddot{\mathrm{O}}_{12}$ \\
\hline & $\begin{array}{l}\text { Duygularını } \\
\text { yönetememe }\end{array}$ & $\ddot{\mathrm{O}}_{3}, \ddot{\mathrm{O}}_{5}, \ddot{\mathrm{O}}_{7}, \ddot{\mathrm{O}}_{10}$ \\
\hline & $\begin{array}{l}\text { Etkinlik - fiziki ortam } \\
\text { uyumsuzluğu }\end{array}$ & $\ddot{\mathrm{O}}_{4}, \ddot{\mathrm{O}}_{8}, \ddot{\mathrm{O}}_{9}$ \\
\hline & Araç-gereç eksikliği & $\ddot{O}_{1}$ \\
\hline \multirow{2}{*}{$\begin{array}{c}\text { Öğrencilerden } \\
\text { kaynaklanan } \\
\text { zorluklar }\end{array}$} & $\begin{array}{l}\text { Aktif katılımın } \\
\text { olmamas1 }\end{array}$ & $\ddot{\mathrm{O}}_{9}, \ddot{\mathrm{O}}_{10}, \ddot{\mathrm{O}}_{11}, \ddot{\mathrm{O}}_{12}$ \\
\hline & Araç-gereç eksikliği & $\mathrm{O}_{5}$ \\
\hline
\end{tabular}

Tablo 2 incelendiğinde; öğretmen adaylarının etkinlik uygulama sürecinde yaşamış oldukları zorluklar, öğretmen adayından ve öğrencilerden kaynaklanan zorluklar olmak üzere iki kategori altında toplanmıştır. Öğretmen adayından kaynaklanan zorluklar kategorisi altında, dört öğretmen adayının ders süresini ayarlayamadıkları için, dört öğretmen adayının sınıf hâkimiyetini sağlayamadıklarından, dört öğretmen adayının duygularını yönetemediği için, üç öğretmen adayının etkinliklerin sınıf ortamına uyumsuz olmasından dolayı problem yaşadıkları görülürken, bir öğretmen adayının ise etkinlikte kullanılacak olan araçgereçlerin eksikliğinden dolayı zorluk yaşadığı görülmektedir. Öğrencilerden kaynaklanan zorluklar arasında, dört öğretmen adayı öğrencilerin aktif katılım göstermemelerinden ve bir öğretmen adayı ise öğrencilerin materyallerinin eksik olmasından dolayı zorluk yaşadıkları görülmüştür.

Öğretmen adaylarından $\ddot{O}_{3}$, etkinlik uygulama sürecinde ders süresini ayarlamakta sıkıntı yaşadığını;

Süre yönünden sıkıntı çektim. Konu anlatımımı bitiremeden etkinliğe geçmek zorunda kaldım. Yetiştiremedim, tamamının olmasını isterdim, ben 20 dakika gibi bir şey tasarlamıştım ama dersin bitmesine 10 dakika kala

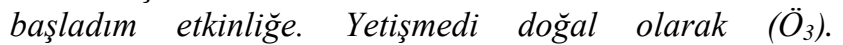

cümleleriyle açıklarken, Ö 9 kodlu öğretmen adayı sınıf hâkimiyetini sağlamakta zorluk yaşadığını;

Sinıf kalabalıkt biraz curcuna oluyor etkinlik sirasında. Hani ders anlatırken olmuyor ama etkinlik sırasında bayağ bir kalabalık oluyor. Etkinlik için ögrencilere ayrl ayrt verdiğin zaman hele daha çok kopuk oluyor. Hani ses falan çıkıyor bu sefer bastıramıyorsun bağırmak zorunda kalıyorsun. Yani sınıf hâkimiyetinde zorlandım (Ö̈). şeklinde ifade etmiştir. Ö${ }_{7}$ kodlu öğretmen aday duygularını yönetemediği için zorluk yaşadığını;

İkinci etkinliğimi yaparken ögrencilere o etkinliğimdeki kare ile çember arasındaki durumu nasıl anlatacağım hakkında heyecandan dolayı sinıfta biraz sorun yaşadım $\left(\ddot{O}_{7}\right)$. sözleriyle belirtirken, öğretmen adaylarından $\ddot{O}_{4}$, sınıf ortamını düşünmeden bir etkinlik planladığı için bir uyumsuzluk problemi yaşadığını;

Hiç istediğim gibi olmadı yani ortam uygun değildi yani üç kutu yan yana koyup da mesela aynı anda ölçtürmek istemiştim ama ögretmen masasına siğmadı. Onu düşünememişim. Herkesin görebileceği bir yer baktım sinıfta ama uygun bir yer bulamadım, stralara da tek tek dağıtamazdım zaten. Böyle bir zorluk yaşadım (Ö̈). ifadeleriyle açıklamıştır. Öğretmen adaylarından $\ddot{O}_{1}$, etkinlikte kullanılacak olan araç-gereçlerin eksikliğinden dolayı sıkıntı yaşadı̆̆ını;

Etkinlikte hocam araç-gereç sıkıntısı yaşadım. Öğrendim ki etkinliği planlarken hani kullanılan araç-gereçleri yazlyoruz ya öncelikle o araç-gereçleri yanına koyacaksın. Ben araç-gereç eksikliğinden dolayı etkinliği iki kere değiştirdim. Yani önceden etkinliği planladım hani bu araçgereçler lazım olur bunlar rahatça bulabilirim diye düşündüm o şekilde planladım. Sonra araç-gereçleri araştırmak için okulun laboratuvarına gittiğimde bulamadım ve etkinliği değiştirdim. Derse on dakika kala yine laboratuvara baktım istediğim bu araç-gereçleri yine bulamadım. Dolaylsıyla etkinliği tekrar değiştirmeye çalıştım. $O$ anda bir stres oldu. Etkinliği yaparken de karlşıklıklar oldu. Yani etkinliği hazırlarken o kullanacağımız araç-gereçler hani ne kullanıyorsak onlar yanında hazır olmalı ki etkinlik derste tam, yüzde yüz performansla çalışsın diye düşünüyorum bunu anladım, yani bunu ögrrendim $\left(\ddot{O}_{1}\right)$. sözleriyle ifade ederken, $\ddot{O}_{12}$ kodlu öğretmen adayı öğrencilerin derse aktif olarak katılmamalarından dolayı bir zorluk yaşadığını;

Illk önce sinıf faktörü zaten, yani öğrencilerin derse aktif olarak katılmaması en büyük zorluk bu oldu benim için $\left(\ddot{O}_{12}\right)$. olarak belirtmiş ve Ö 5 kodlu öğretmen adayı ise bütün öğrencilerin etkinlikte kullanılacak olan araç-gereçleri getirmemelerinden dolayı bir sıkıntı yaşadığını;

Etkinlikte kullanılacak birkaç araç-gereç malzeme gerekiyordu, ögrencilere bu araç-gereçleri getirmelerini önceden söylemiştim fakat bütün ögrenciler bu malzemeleri getirmediğinden bir sıkıntı da bu oldu $\left(\ddot{O}_{5}\right)$. cümlesiyle dile getirmiştir. 
Tablo 3. Adayların Uygulama Sürecinde Karşılaştıkları Zorlukları Aşmak için Neler Yaptıklarına Yönelik Görüşleri

\begin{tabular}{|c|c|c|}
\hline Tema & Kod & Öğretmen Adayı \\
\hline \multirow{7}{*}{$\begin{array}{c}\text { Süreçte } \\
\text { karşılaş1lan } \\
\text { zorluklar }\end{array}$} & $\begin{array}{l}\text { Etkinlik planında } \\
\text { değişiklik }\end{array}$ & $\ddot{\mathrm{O}}_{3}, \ddot{\mathrm{O}}_{4}, \ddot{\mathrm{O}}_{5}, \mathrm{O}_{8}, \ddot{\mathrm{O}}_{12}$ \\
\hline & Sözlü uyarıda bulunma & $\ddot{O}_{9}, \ddot{O}_{10}$ \\
\hline & $\begin{array}{l}\text { Ödülü hatırlatma ihtiyacı } \\
\text { duyma }\end{array}$ & $\ddot{\mathrm{O}}_{2}$ \\
\hline & $\begin{array}{l}\text { Alternatif araç-gereç } \\
\text { kullanma }\end{array}$ & $\ddot{O}_{1}$ \\
\hline & $\begin{array}{l}\text { Öğrencilere araç-gereç } \\
\text { temini }\end{array}$ & $\ddot{O}_{5}$ \\
\hline & Ders sürecini hızlandırma & Ö$_{6}$ \\
\hline & Çaresizlik & $\ddot{\mathrm{O}}_{7}, \ddot{\mathrm{O}}_{11}$ \\
\hline
\end{tabular}

Tablo 3 incelendiğinde; öğretmen adaylarından beşinin etkinlik uygulama sürecinde karşılaştıkları zorlukları aşmak için etkinlik planında o an için değişiklik yaptıkları, ikisinin sözlü uyarıda bulundukları ve birer öğretmen adayının ise ödülü hatırlatma ihtiyacı duymak zorunda kaldı ̆̆ı, alternatif araç-gereç kullandığı, öğrencilere araç-gereç temin ettiği ve ders sürecini hızlandırdığı görülmektedir. Diğer taraftan iki öğretmen adayının ise bu süreçte karşılaştığı zorlukları aşmak için ellerinden bir şey gelmeyerek çaresiz kaldıklarını ifade ettikleri görülmüştür.

Öğretmen adaylarından $\mathrm{O}_{4}$, etkinlik uygulama sürecinde yaşamış olduğu zorlukları aşmak için etkinlik planında değişiklik yapmak durumunda kaldığını;

$O$ an neler yaptım, biraz panikledim açıkçası. Sonra tek tek ölçtürdüm prizmaları. Tek tek yaptırmak zorunda kaldım. Biraz etkinlik planımın dışına çıktım açıkçası, uygulama şeklinin dışına çıktım. Ama amacına ulaştı diye düşünüyorum $\left(\ddot{O}_{4}\right)$. şeklinde ifade ederken, Ö öğretmen adayı öğrencilere sözlü uyarıda bulunmak zorunda kaldığını;

Yani hani ses tonumu yükselterek çocukların bana yönelmesini, biraz daha etkinliklerin üzerinde uğraşmalarını săglamaya çalıştım ya da mesela başka şeyle uğraşan o siralarla tek tek ilgilendim hani bunu yapacă̆ı, nasil yapabiliriz, birebir sorular sordum. Böylece o sıkıntıları atlattığımı düşünüyorum $\left(\ddot{O}_{10}\right)$. sözleriyle belirtmiştir. $\ddot{O}_{2}$ kodlu öğretmen adayı öğrencileri etkinliğe katılmaya teşvik etmek için etkinlik sonunda ödüllendirme durumunu hatırlatma ihtiyacı duyduğunu;

Neler yaptım, hani mesela etkinliğin sonucunda ödül vereceğimi söyledim. Isşte uslu dururlarsa güzel bir etkinlik olacağını, yine hani ödülle daha çok, sonucunda ödül olduğunu söyleyince zaten hemen herkes etkinliğe hazır oldu $\left(\ddot{O}_{2}\right)$. ifadeleriyle açıklarken, ögrretmen adaylarından Ö$_{1}$ alternatif araç-gereç kullanarak yaşamış olduğu sıkıntıyı aşmaya çalıştığını;

$O$ an hocam hemen yani etkinlikte ki başta neyi kullanacaksam onu hani o materyali bulamadım ya bulduğumu hemen uyarlamaya çalıştım. Tabi orada da bazı özellikler kayboldu. Mesela benim için yükseklik önemliydi hani o büyük kapları bulabilseydim daha rahat görülecekti. O büyük olanı bulamadım küçük buldum. 400 milimlik beherglas buldum, orada yükseklikler hassastı biraz kayboldu. Hani cetvelle ölçeceğim vs. birinde sivı miktarı çok az olacak 0,4 desilitreyi yani çok hassas santimlerle, milimlerle ölçecek ögrenci. Dolayısıly doğru bir ölçüm olmadı. Orada hani yüksekliklerle 10 kat oranını bulduracaktım. Öyle bir sıkıntı oldu yani etkinliği tam uygulayamadım. Yani istediğim materyal olsaydı daha güzel olacaktı ama alternatifini yine yapmaya çalıştım. Ama etkinliğin amacındaki o hassasiyetlik kayboldu ( $\left.\ddot{O}_{1}\right)$. cümleleriyle dile getirmiştir. Ö 5 kodlu öğretmen adayı etkinlikte kullanılacak olan araç-gereçleri getirmeyen öğrencilere araç-gereç temini sağlayarak yaşamış olduğu sıkıntıyı aşmaya çalıştığını;

$O$ an mesela ben önceden hazırladığım bazı öğrencilerin getirmeyebileceğini düşündüğ̈̈m şeyleri getirerek önlem aldım. Konum çember olduğu için çember kestim. Hani makası olmayan, pergeli olmayan öğrenciler için önceden hazırlanmış materyali onlara verdim ki onlarda sınıftan geri kalmasınlar. Bu da işe yaradı. Öğrencilerin çoğu getirmemişti zaten. Onlara hani bu materyalleri vererek aktif katılımı sağlamaya çalıştım $\left(\ddot{O}_{5}\right)$. açıklamalarıyla anlatırken, Ö 6 kodlu öğretmen adayı ise ders sürecini hızlandırmak durumunda kaldığını;

Daha hızlandırmaya çalıştım, sonra en son fark ettim dersin bitmesine son 15 dakika kaldığını, yazmayı birakıp direk etkinliklere giriştim. Sonra tekrar soru yazdırma aşamasına geldiğimde zil çalmıştı dolayısıyla etkinliklerim tam olarak yetişmedi $\left(\ddot{O}_{6}\right)$. şeklinde ifade etmiştir. Diğer taraftan ögretmen adaylarından $\ddot{O}_{7}$ ise heyecanının neden olduğu zorlukları aşmak için elinden bir şey gelmediğini ve çaresiz kaldığını;

Kare ile çember arasındaki ilişkiyi ögrencilere nasıl anlatacă̆ım konusunda pek bir şey yapamadım. Önceden bu konuda fikir aldığım bir hocanın söylediklerini uygulamaya çalıştım sadece $\left(\ddot{O}_{7}\right)$. sözleriyle belirtmiştir.

Adaylara ikinci olarak "Etkinlik uygulama sürecinde matematiksel terim ve kavramların ifadelerine yönelik herhangi bir hata yapıp yapmadığınıza yönelik ne düşünüyorsunuz?" sorusu yöneltilmiş olup adayların bu soruya verdikleri cevaplardan elde edilen bulgulara Tablo 4 'te yer verilmiştir.

Tablo 4. Adayların Uygulama Sürecinde Matematiksel Terim ve Kavramların İfadelerinde Yaptıkları Hatalara Yönelik Görüşleri

\begin{tabular}{|c|c|c|}
\hline Tema & Kod & Öğretmen Adayı \\
\hline \multirow{3}{*}{$\begin{array}{c}\text { Matematiksel } \\
\text { terim ve } \\
\text { kavramlar }\end{array}$} & Hata yaptım & $\ddot{\mathrm{O}}_{3}, \ddot{\mathrm{O}}_{7}, \ddot{\mathrm{O}}_{12}$ \\
\hline & Hata yapmadım & $\ddot{\mathrm{O}}_{2}, \ddot{\mathrm{O}}_{4}, \ddot{\mathrm{O}}_{8}$ \\
\hline & Görüş yok & $\ddot{\mathrm{O}}_{1}, \mathrm{O}_{5}, \ddot{\mathrm{O}}_{6}, \ddot{\mathrm{O}}_{9}, \mathrm{Ö}_{10}, \mathrm{Ö}_{11}$ \\
\hline
\end{tabular}

Tablo 4 incelendiğinde; öğretmen adaylarından üçünün hata yaptığını ve üçünün etkinlik uygulama sürecinde herhangi bir hata yapmadığını ifade ettikleri görülürken, altı öğretmen adayının ise hata yapıp yapmadıklarıyla ilgili görüş bildirmedikleri görülmektedir.

Öğretmen adaylarından $\ddot{O}_{3}$, hacim ölçme konusuna yönelik hazırladığı bir etkinliği uygularken kavramsal anlamda hata yaptığını;

Evet yaptım. Kare dik prizmaya bir kaç defa dikdörtgenler prizması dedim ve o şekilde tanımladım, tabana göre isimlendirildiğini ifade ettim. Çünkü prizmaların bu şekilde yani tabana göre isimlendirildiğini biliyordum. Sonra bir ögrencinin düzeltmesiyle bu durumu fark ettiğim halde bu yanlışımı devam ettirdim çünkü sonradan çeviremedim 
$\left(\ddot{O}_{3}\right)$. ifadeleriyle belirtmiştir. $\ddot{O}_{3}$ kodlu öğretmen adayının etkinlik sürecinde yapmış olduğu bu hataya ait bir görsel öge Şekil 1'de yer almaktadır.

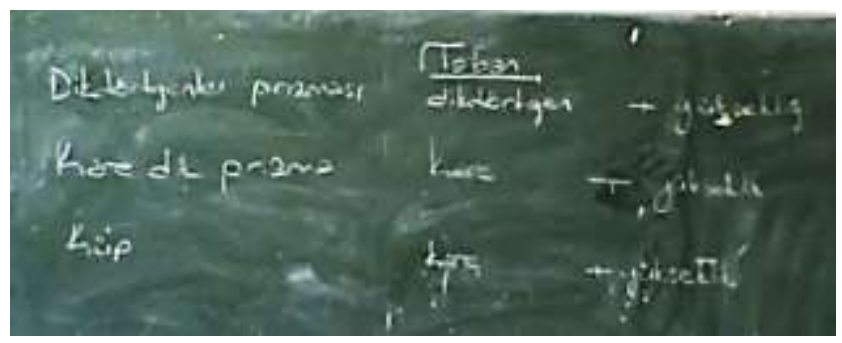

Şekil 1. Ö3’ün uygulama sürecinde yaptığı hataya ait görsel öge

$\ddot{O}_{7}$ kodlu öğretmen adayı ise çemberin ve çember parçasının uzunluğu konusuna yönelik hazırladığ1 bir etkinliğin uygulanma sürecinde yaptığı kavramsal bir hatayı;

Evet, hata yaptığımı dersten sonra tahtaya bakınca fark ettim. Pi saylsını 3 olarak alın diyeceğim yerde $3 \mathrm{~cm}$ olarak alın demişim. Pi'nin biriminin olmadığını bilmeme ră̆men vaktim azaldığından dolayı sanırım hızlı anlatmak için, çünkü süreyi de sürekli kontrol ediyorum, o yüzden hızlıca öyle yazmışım tahtaya $\left(\ddot{O}_{7}\right)$. sözleriyle ifade etmiştir. $\mathrm{O}_{7}$ kodlu öğretmen adayının etkinlik sürecinde yapmış olduğu bu hataya ait bir görsel öge Şekil 2'de yer almaktadır.

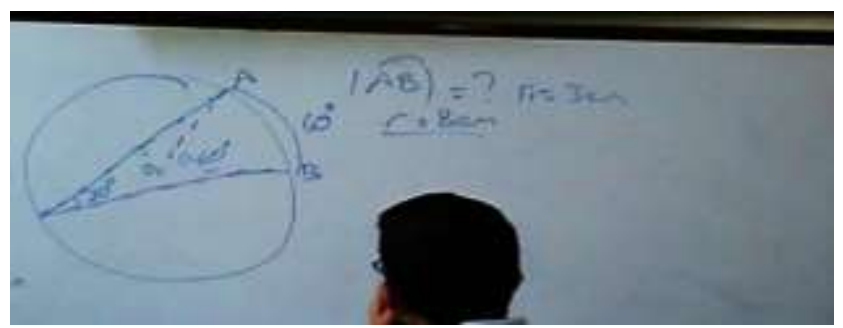

Şekil 2. Ö7'nin uygulama sürecinde yaptığı hataya ait görsel öge

Ö$_{12}$ kodlu öğretmen adayı yapmış olduğu hataları;

Matematiksel anlamda bă̆ıntıyı oluştururken karıştırdım ne yapacă̆ımı bilemedim. Sonradan hani kafamdan hazırladım bağıntıyı ama çıkaramadım. Ayrıca açıları, yaylarl, kenarlarl falan tam olarak ifade edemediğimi düşünüyorum. Mesela doğru parçası diyeceğim yerde işte çizgi falan dedim. $O$ şekilde hatalar yaptım iyi hazırlanamadiğım için $\left(\ddot{O}_{12}\right)$. cümleleriyle açıklamıştır. Diğer taraftan $\ddot{O}_{2}$ kodlu öğretmen adayı etkinlik uygulama sürecinde herhangi bir hata yaptığını düşünmediğini;

Yok, hani zannetmiyorum çünkü zaten vereceğim kavramları ilk etkinliğimde verdiğim için sonrass bunu değerlendirmeye yönelikti. Kavramlarl falan verirken de herhangi bir hata yapmadım öyle hatırlıorum ( $\left.\ddot{O}_{2}\right)$. şeklinde dile getirirken, $\mathrm{O}_{4}$ kodlu öğretmen adayı bu süreçte herhangi bir hata yapmadığını;

Herhangi bir hata yaptı̆̆ımı düşünmüyorum, amacımın dışına çıkmadım çünkü $\left(\ddot{O}_{4}\right)$. olarak ifade etmiştir. Ancak bu öğretmen adayı hacim ölçme konusuna yönelik hazırladığ1 bir etkinliği uygulama sürecinde prizmaları (dikdörtgen, kare ve küp) tanıtırken tabanlarına göre isimlendirmiştir. Öğretmen adayına prizmaları isimlendirirken yaptı̆̆ hata hatırlatıldığında, prizmaların isimlendirmesinin bu şekilde yapıldığını bildiğini belirtmiştir. Yine $\mathrm{O}_{4}$ kodlu öğretmen adayı hazırladığı bir diğer etkinliği uygularken öğrencilere boş A4 kâğıdı dağıtmıș ve öğrencilere bu kâğıtları katlatarak prizma modelleri oluşturtmuş ancak bu prizmaların karşılıklı birer yüz çiftinin kâğıtla kaplı olmamasına rağmen, öğretmen adayı öğrencilerde kavram yanılgısı oluşmaması adına herhangi bir uyarıda bulunmamıştır. Ö 4 kodlu öğretmen adayının etkinlik sürecinde yapmış olduğu bu hataya ait bir görsel öge Şekil 3 'te yer almaktadır.

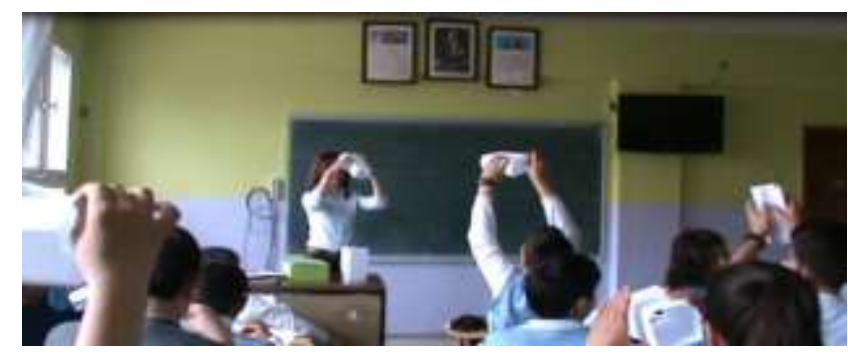

Şekil 3. Ö 4 'ün uygulama sürecinde yaptığı hataya ait görsel öge

Ös kodlu öğretmen adayı da yine herhangi bir hata yaptığını düşünmediğini;

Genel olarak doğru bilgileri verdiğimi düşünüyorum. Şuan için aklıma gelen bir şey yok $\left(\ddot{O}_{8}\right)$. açıklamasıyla belirtmiştir. Ancak Ö 8 kodlu öğretmen adayı çemberin ve çember parçasının uzunluğu konusuna yönelik hazırladığ1 bir etkinliği uygularken " $\pi=\frac{143 \mathrm{~cm}}{44 \mathrm{~cm}}$ " ifadesini yazarak bunu "orantı" olarak ifade etmiştir. Ayrıca yine bu öğretmen adayı " $\pi$ sayısını" birkaç yerde birimli olarak ifade ederek tahtaya " $\pi=\frac{\text { Çevre }}{\text { Cap }}=\frac{143 \mathrm{~cm}}{44 \mathrm{~cm}} \cong 3 \mathrm{~cm}$ " ve " $(\pi=$ $3 \mathrm{~cm}$ alınız)" ifadelerini not etmiştir. Öğretmen adayına yaptığı bu hatalar hatırlatılarak bu hatalarının nedeni sorulduğunda heyecandan kaynaklanmış olabileceğini belirtmiştir. Ö 8 kodlu öğretmen adayının etkinlik sürecinde yapmış olduğu bu hatalara ait görsel ögeler Şekil 4'te yer almaktadır.
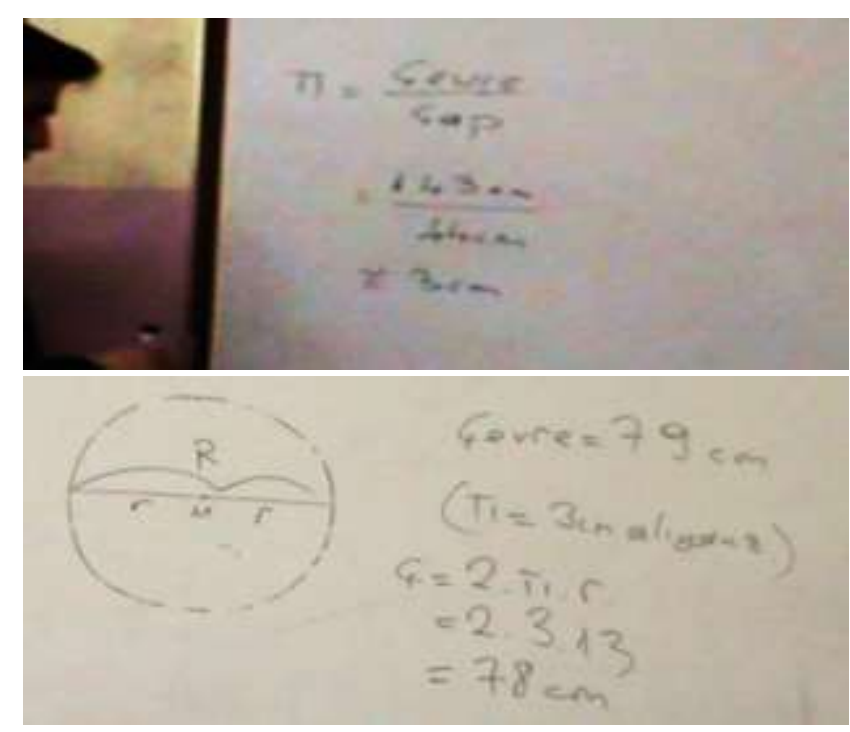

Şekil 4. Ö 8 'in uygulama sürecinde yaptığı hatalara ait görsel öge

Etkinlik uygulama sürecinde herhangi bir hata yapıp yapmadığına dair görüş bildirmeyen öğretmen adaylarından Ö$_{10}$, Açıkçası fark etmedim çünkü inanın bana ben o an ne 
konuştuğumu bile çoğunu hatırlamıyorum bile. Tamam, belki bilinçli bir şeyler söylüyorum ama söylediğimi an bitiyor, kalmıyordu kafamda heyecandan $\left(\ddot{O}_{10}\right)$. şeklindeki sözleriyle uygulama sürecinde herhangi bir hata yapıp yapmadığını fark etmediğini ifade etmiştir.

Tablo 4'te Ö 1 kodlu öğretmen adayının uyguladığ1 etkinlikte matematiksel terim ve kavramların ifadelerine yönelik hata yapıp yapmamasıyla ilgili herhangi bir görüş bildirmediği görülmektedir. Ancak bu öğretmen aday1 sıvıları ölçme konusuna yönelik hazırladığı etkinliği uygularken sıvı ölçü birimlerinden "desimetreküp” birimini ifade ederken "desilitreküp" olarak ifade etmiş ve tahtaya " $1 \mathrm{~L}=1 \mathrm{dm}^{3}$ " yazması gerekirken " $1 \mathrm{~L}=1 \mathrm{dl}$ " olarak yazdığı görülmüştür. Öğretmen adayına yapmış olduğu hata hatırlatılarak bu hatasının nedeni sorulduğunda, heyecandan kaynaklanmış olabileceğini ifade etti. $\mathrm{Bu}$ öğretmen adayının etkinlik sürecinde yapmış olduğu bu hataya ait bir görsel öge Şekil 5'te yer almaktadır.

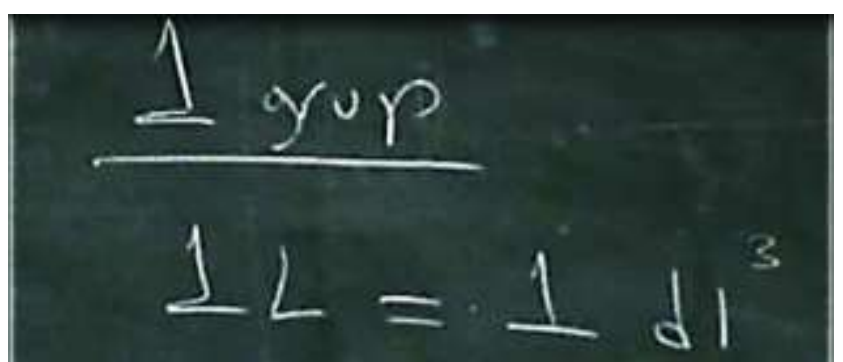

Şekil 5. Öı' 'in uygulama sürecinde yaptığı hataya ait görsel öge

Tablo 4'e bakıldığında, Ö 5 kodlu öğretmen adayının da uyguladığı etkinlikte matematiksel terim ve kavramların ifadelerine yönelik hata yapıp yapmamasıyla ilgili herhangi bir görüş bildirmediği görülmektedir. Ancak bu öğretmen adayı çemberde açı konusuna yönelik hazırladığı bir etkinliği uygularken matematiksel bir kavram olan açıyı "İki doğru arasında kalan aralık ama iki doğrunun başlangıç noktalarının aynı olması gerekir" şeklinde tanımlayarak öğrencilerde kavram yanılgılarına sebep olabilecek bir duruma sebep olmuştur. Öğretmen adayına yapmış olduğu bu hata hatırlatıldığında ise adayın böyle bir hata yaptığını hiç fark etmediğini ifade etmiştir.

Yine Tablo 4'te Ö 10 kodlu öğretmen adayının uyguladığ1 etkinlikte matematiksel terim ve kavramların ifadelerine yönelik hata yapıp yapmamasıyla ilgili herhangi bir görüş bildirmediği görülmektedir. Ancak bu öğretmen adayı da geometrik cisimlerin (üçgen, kare ve dikdörtgen prizmalar) yüzey alanları konusuna yönelik hazırladığı bir etkinliği uygulama sürecinde prizmaları tanıtırken tabanlarına göre isimlendirmiştir. Öğretmen adayına prizmaları isimlendirirken yaptığı bu hata hatırlatıldığında, prizmaların isimlendirmesinin bu şekilde yapıldığını bildiğini belirtmiştir.

Adaylara yöneltilen "Etkinlik uygulama sürecinde gözlemlediğiniz öğrenci tutumları nasıldı?" şeklindeki üçüncü soruya verilen cevaplardan elde edilen bulgular Tablo 5 'te yer almaktadır.
Tablo 5. Adayların Uygulama Sürecinde Gözlemledikleri Öğrenci Tutumlarına Yönelik Görüşleri

\begin{tabular}{cll}
\hline Tema & Kod & Öğretmen Adayı \\
\hline \multirow{2}{*}{$\begin{array}{c}\text { Öğrenci } \\
\text { tutumları }\end{array}$} & İstekli ve olumlu & $\ddot{\mathrm{O}}_{1}, \ddot{\mathrm{O}}_{2}, \ddot{\mathrm{O}}_{3}, \ddot{\mathrm{O}}_{4}, \ddot{\mathrm{O}}_{5}$, \\
\cline { 2 - 3 } & $\ddot{\mathrm{O}}_{6}, \mathrm{Ö}_{7}, \ddot{\mathrm{O}}_{8}, \ddot{\mathrm{O}}_{9}, \ddot{\mathrm{O}}_{10}$ \\
\hline
\end{tabular}

Tablo 5 incelendiğinde; on öğretmen adayının etkinlik uygulama sürecinde öğrencilerin istekli ve olumlu tutum sergilediklerini ve iki öğretmen adayının ise öğrencilerin olumsuz ve isteksiz tutum sergilediklerini gözlemledikleri görülmektedir.

Öğretmen adaylarından $\mathrm{Ö}_{1}$, öğrencilerin etkinlik uygulama sürecinde istekli ve olumlu bir tutum sergilediklerini;

Öğrencileri ben en başta gruplara bölmüştüm hocam, beş tane gruptu. Grup grup şeklinde bir oturma plant yaptığımda öğrencilerde şaşırdı, hoşlarına da gittiğini fark ettim. Ben sonradan dedim her grubun bir tane başkanı olacak ve grupların başkanlarını seçtim. Sonra materyalleri, malzemeleri verdiğim zaman işte herkes mesela eline ald, bakmaya çalıştı hani o şekilde uğraştı falan. Yani hepsi etkinliğe katılmaya yöneldi, olumlu tepkileri oldu. Yani hepsi de etkinliğe istekli oldu. Çünkü sinıfi o şekilde oturtmam daha hoşlarına gitti, öyle gördüm. Zaten ders bittiğinde ögrenciler ögretmenlerine biz hep bu şekilde oturalım dediler $\left(\ddot{O}_{1}\right)$. sözleriyle ifade ederken, $\ddot{O}_{11}$ kodlu öğretmen adayı ise bu süreçte öğrencilerin isteksiz ve olumsuz bir tavır takındıklarını;

Olumlu olmadl. Yani dalga geçtiler diyebilirim. Işste hani dersi dinlemek istemediklerinden etkinliği de yapmak istemediler. Yani hiç bir şekilde ilgilenmediler. Bu durumu da ben ögrencilerin gelişim dönemlerine vermek istiyorum. 8. sınıf oldukları için şuan tamamen öyle düşüncem $\left(\ddot{O}_{11}\right)$. şeklinde ifade etmiştir.

Adaylara yöneltilen "Etkinlik uygulama süreciyle ilgili kendinizi nasıl değerlendiriyorsunuz?” şeklindeki dördüncü soruya verilen cevaplardan elde edilen bulgular Tablo 6'da sunulmuştur.

Tablo 6. Adayların Uygulama Süreci ile İlgili Kendilerini Nasıl Değerlendirdiklerine Yönelik Görüşleri

\begin{tabular}{cll}
\hline \multicolumn{1}{c}{ Tema } & Kod & Öğretmen Adayı \\
\hline \multirow{2}{*}{ Özdeğerlendirme } & Yetersiz & $\ddot{\mathrm{O}}_{1}, \ddot{\mathrm{O}}_{3}, \ddot{\mathrm{O}}_{4}, \ddot{\mathrm{O}}_{6}, \ddot{\mathrm{O}}_{11}, \ddot{\mathrm{O}}_{12}$ \\
\cline { 2 - 3 } & $\begin{array}{l}\text { Kismen } \\
\text { yetersiz/yeterli }\end{array}$ & $\ddot{\mathrm{O}}_{5}$ \\
\cline { 2 - 3 } & Yeterli & $\ddot{\mathrm{O}}_{2}, \ddot{\mathrm{O}}_{7}, \ddot{\mathrm{O}}_{8}, \ddot{\mathrm{O}}_{9}, \ddot{\mathrm{O}}_{10}$ \\
\hline
\end{tabular}

Tablo 6 incelendiğinde; altı öğretmen adayının etkinlik uygulama süreciyle ilgili kendilerini yetersiz olarak değerlendirdiği görülürken, bir öğretmen adayının kısmen yetersiz/yeterli olarak değerlendirdikleri ve beş öğretmen adayının ise kendilerini yeterli olarak değerlendirdikleri görülmektedir.

Öğretmen adaylarından $\mathrm{O}_{1}$, etkinlik uygulama sürecine dair kendini yetersiz olarak gördüğünü;

Bayağ bir yetersiz olduğumu düşünüyorum yani. Etkinlikte düşündüğümü tam olarak uygulayamadım. Hani tam aklımdaki tasarıyı ögrenciye veremedim $\left(\ddot{O}_{1}\right)$. sözleriyle ifade ederken, $\ddot{\mathrm{O}}_{3}$ kodlu öğretmen adayı ise yetersiz olduğunu; 
Kendimi çok yetersiz gördüm. Illk başta toparlayamadım sonra cümleleri kuramadım. Yani böyle çocukların karşısında tedirgin olmak istemiyordum ama öyle oldu $\left(\ddot{O}_{3}\right)$. şeklinde açıklamıştır. Ö 5 kodlu öğretmen adayı etkinlik uygulama sürecinde kendini kısmen yetersiz/yeterli olarak gördüğünü;

Şuan için kısmen yeterli olduğumu düşünüyorum. Biraz daha üstüne koyarsam herhalde iyi olabileceğimi düşünüyorum. Dolayısıyla kendimi biraz daha geliştirmem gerektiğini düşünüyorum $\left(\ddot{O}_{5}\right)$. açıklamalarıyla belirtmiştir. Diğer taraftan öğretmen adaylarından $\ddot{O}_{2}$, etkinlik uygulama sürecinde kendini yeterli olarak değerlendirdiğini;

Kendimi aslında iyi değerlendiriyorum. Çünkü etkinlikte hani o anda da aklıma gelen doğaçlama yaptığım şeyler oldu. O yüzden iyi olduğumu düşünüyorum açıkçası. Hani sonradan bir şeyler katabildim. Daha değiştirebildim hani farklılaştırabildim. İyi oldu bence, iyi yaptığımı düşünüyorum yani $\left(\ddot{O}_{2}\right)$. ifadeleriyle dile getirirken, öğretmen adaylarından Ö$_{8}$ ise kendini yeterli olarak gördüğünü;

Yani çalıştı̆̆ımı uyguladım diyebilirim aslında. İlk başta etkinlik hazırlama kısmında zorlansam da uygulamada başarllı olduğumu düşünüyorum (Ö̈). cümleleriyle ifade etmiştir.

Yapılan görüşmelerde beșinci olarak adaylara yöneltilen "Etkinlik uygulama sürecindeki gözlemlerinize göre, etkinliklere dayall bir ögretim sürecinin öğretmenlere ne gibi faydalar sağladı̆̆ını düşünüyorsunuz?" şeklindeki soruya verilen cevaplardan elde edilen bulgulara Tablo 7'de yer verilmiştir.

Tablo 7. Adayların Etkinliklere Dayalı Bir Öğretim Sürecinin Öğretmenlere Sağladığı Faydalara Yönelik Görüşleri

\begin{tabular}{|c|c|c|}
\hline Tema & Kod & Öğretmen Adayı \\
\hline \multirow{4}{*}{$\begin{array}{c}\text { Öğretmenlere } \\
\text { sağlanan faydalar }\end{array}$} & $\begin{array}{l}\text { Derse karşı motive } \\
\text { etme }\end{array}$ & $\begin{array}{l}\ddot{\mathrm{O}}_{1}, \ddot{\mathrm{O}}_{2}, \ddot{\mathrm{O}}_{3}, \ddot{\mathrm{O}}_{4}, \ddot{\mathrm{O}}_{6}, \\
\ddot{\mathrm{O}}_{7}, \ddot{\mathrm{O}}_{8}, \ddot{\mathrm{O}}_{9}, \ddot{\mathrm{O}}_{10}, \ddot{\mathrm{O}}_{12}\end{array}$ \\
\hline & $\begin{array}{l}\text { Konuyu kavratmayı } \\
\text { kolaylaştırma }\end{array}$ & $\begin{array}{l}\ddot{\mathrm{O}}_{1}, \ddot{\mathrm{O}}_{2}, \ddot{\mathrm{O}}_{3}, \ddot{\mathrm{O}}_{4}, \ddot{\mathrm{O}}_{5}, \\
\ddot{\mathrm{O}}_{7}, \mathrm{O}_{8}, \ddot{\mathrm{O}}_{9}, \ddot{\mathrm{O}}_{10}, \mathrm{O}_{11}\end{array}$ \\
\hline & $\begin{array}{l}\text { Mesleki gelişime } \\
\text { yardımcı olma }\end{array}$ & $\ddot{\mathrm{O}}_{5}, \ddot{\mathrm{O}}_{6}, \ddot{\mathrm{O}}_{11}$ \\
\hline & $\begin{array}{l}\text { Yaratıcı düşünme } \\
\text { gücünü geliştirme }\end{array}$ & $\ddot{O}_{1}, \ddot{O}_{5}$ \\
\hline
\end{tabular}

Tablo 7 incelendiğinde; etkinliklere dayalı bir öğretim sürecinin öğretmenlere sağladığı faydalara yönelik on öğretmen adayının etkinliklerin öğretmenleri derse karş1 motive ettiğini, on öğretmen adayının öğretmenlerin konuyu kavratmalarını kolaylaştırdığını, üç öğretmen adayının öğretmenlerin mesleki gelişimlerine yardımcı olduğunu ve iki öğretmen adayının ise öğretmenlerin yaratıcı düşünme gücünü geliştirmelerine yardımcı olduğunu ifade ettikleri görülmektedir.

Öğretmen adaylarından $\ddot{O}_{1}$, etkinliklere dayalı bir öğretim sürecinin öğretmeni motive ettiğini;

Yani düz anlattı̆̆ın zaman ögrenci soru sormuyor, ilgilenmiyor, derse katılmıyor. Öğretmen öyle kendi kendine anlatabiliyor bazen. Bir kaç kişiye ders anlattığı oluyor, işte o zaman bu onu gerçekten olumsuz motive ediyor ama ögrencinin derse katıldı̆̆ını görmesi, aktif olması, ögrrenmek istemesi, merak etmesi öğretmeni çok fazla motive ettiğini düşünüyorum $\left(\ddot{O}_{1}\right)$. sözleriyle belirtirken, $\mathrm{O}_{10}$ kodlu öğretmen adayı etkinliklerin, öğretmenlerin konuyu kavratmalarını kolaylaştırdığını;

Ya hocam şöyle bir şey var, sonuçta bizim amacımız ögrencilere bir şeyler vermek, bir şeyler anlatmak, bunun için çaballyoruz. Dolayısıyla etkinlik işin içine girince aslında hani şöyle düşünülüyor ya öğretmenin işi daha zorlaşıyor, yok bunu hazırlayacak, yok şöyle yapacak diye. Ama aslında bizim gayemiz anlatmak olduğu için etkinlikle daha kolay oluyor. Çocuklara etkinlikle konuyu daha rahat ve kolay kavrattyorsun. Çocuk soyuttan ziyade somutu daha rahat algıladığ için, görerek yaşayarak anladı ̆ğ için, bizim için kolay oluyor $\left(\ddot{O}_{10}\right)$. şeklinde açıklamıştır. Diğer taraftan Ö$_{6}$ kodlu öğretmen adayı, etkinliklere dayalı bir öğretim sürecinin öğretmenlerin mesleki gelişimlerine yardımcı olduğunu;

Mesleki anlamda yeterli olmamızı daha çok sağllyor. Etkinlik tasarladiğım için daha çok hangi konuya odaklanmam gerekiyor? Bu konunun tam olarak kapsamı nedir? Çocuklar bana hangi kısımlarda farklı sorular sorabilir? Onlara en azından etkinlikler aracıliğılyla dikkat ederek falan benim mesleki anlamda daha yeterli olmami, doyum sağlamamı sağlıyor $\left(\ddot{O}_{6}\right)$. cümleleriyle ifade ederken, Ö 5 kodlu ögrretmen adayı ise bu şekildeki bir öğretim sürecinin öğretmenlerin yaratıcı düşünme gücünü geliştirdiğini ve yine mesleki gelişimlerine yardımcı olduğunu;

Öğretmenlere birincisi mesela yaratıcı düşünme. Ögretmenler hani bunu daha iyi nastl anlatabilirim, nasıl somutlaştırabilirim, nasıl aktif katılımı sağlayabilirim şeklinde düşünerek yaratıcı düşünmelerini geliştirir. Bir ikincisi örneğin diyelim birinci yll bir şekilde etkinliğini anlatmış birisi ögrencilerden geri dönüt alarak ikinci yıl onu daha iyi geliştirerek sunabilir. Bu da her sene hani kendi düşüncesine kendi bilgilerine bir şeyler daha katarak mesleki anlamda ilerlemesini sağlar $\left(\ddot{O}_{5}\right)$. sözleriyle dile getirmiştir.

Adaylara son olarak yöneltilen "Etkinlik uygulama sürecindeki gözlemlerinize göre, etkinliklere dayall bir ögretim sürecinin öğrencilere ne gibi faydalar să̆ladığını düşünüyorsunuz?" şeklindeki altıncı soruya verilen cevaplardan elde edilen bulgular Tablo 8'de sunulmuştur.

Tablo 8. Adayların Etkinliklere Dayalı Bir Öğretim Sürecinin Öğrencilere Sağladığı Faydalara Yönelik Görüşleri

\begin{tabular}{|c|c|c|}
\hline Tema & Kod & Öğretmen Adayı \\
\hline \multirow{3}{*}{$\begin{array}{c}\text { Öğrencilere } \\
\text { sağlanan faydalar }\end{array}$} & $\begin{array}{l}\text { Kalıcı } \\
\text { öğrenme }\end{array}$ & $\begin{array}{l}\ddot{O}_{1}, \ddot{\mathrm{O}}_{2}, \ddot{\mathrm{O}}_{3}, \ddot{\mathrm{O}}_{4}, \ddot{\mathrm{O}}_{5}, \ddot{\mathrm{O}}_{6}, \\
\ddot{\mathrm{O}}_{7}, \mathrm{O}_{8}, \ddot{\mathrm{O}}_{9}, \ddot{\mathrm{O}}_{10}, \ddot{\mathrm{O}}_{11}, \ddot{\mathrm{O}}_{12}\end{array}$ \\
\hline & $\begin{array}{l}\text { Derse ilgi } \\
\text { duyma }\end{array}$ & $\ddot{\mathrm{O}}_{1}, \ddot{\mathrm{O}}_{4}, \ddot{\mathrm{O}}_{9}, \ddot{\mathrm{O}}_{10}, \ddot{\mathrm{O}}_{11}$ \\
\hline & $\begin{array}{l}\text { Bakış açısını } \\
\text { geliştirme }\end{array}$ & $\ddot{O}_{11}$ \\
\hline
\end{tabular}

Tablo 8 incelendiğinde; 12 öğretmen adayının tamamının etkinliklere dayalı bir öğretim sürecinin öğrencilerin kalıcı öğrenmelerini sağladığını, beş öğretmen adayının öğrencilerin derse ilgi duymalarını sağladığını ve bir öğretmen adayının ise öğrencilerin bakış açılarını geliştirmelerine yardımcı olduğunu ifade ettikleri görülmektedir.

Öğretmen adaylarından Ö$_{12}$ etkinliklere dayalı bir öğretim sürecinin öğrencilerin kalıcı öğrenmelerini sağladığını; 
Yani ögrrenci somut olarak görüyor, ne olduğunu anllyor, hani düz anlatımda sadece formülü yazıyorsun falan ama burada koniyi açıyorsun kendin yaplyorsun, kendin görüyorsun ve doğruymuş diyorsun. Dolayısıyla daha kalıcı bir ögrenme sağllyorsun $\left(\ddot{O}_{12}\right)$. şeklinde ifade ederken, Ö 9 kodlu öğretmen adayı öğrencilerin derse karşı ilgi duymalarını sağladığını;

Daha iyi anlamalarını sağlıyor. Hani onun dışında da ilgi çektiği için derse katılımlarını artırıyor ve böylece derse ilgi duymalarını sağlıyor $\left(\ddot{O}_{9}\right)$. olarak belirtirken, öğretmen adaylarından $\ddot{O}_{11}$ ise bu şekildeki bir öğretim sürecinin öğrencilerin bakış açılarını geliştirdiğini;

Daha iyi ögrenirler, matematiğe karşı daha da hoşnut olurlar, bakış açıları değişir. Matematiğin sadece sayılardan ibaret olmadığını, çünkü materyal, etkinlik yaptığımız zaman bunu günlük hayatla da ilişkilendiriyoruz, başka derslerle de ilgisini, ilişkisini kuruyoruz. Bu da onların bakış açılarını geliştirmelerini sağlar ( $\left.\ddot{O}_{11}\right)$. sözleriyle açıklamıştır.

\section{Sonuç, Tartışma ve Öneriler}

Öğretmen adaylarının etkinlik uygulama sürecinde yaşadıkları zorluklara yönelik görüşleri incelediğinde; bu zorluklar, öğretmen adayından ya da öğrencilerden kaynaklanan zorluklar olarak iki kategoride değerlendirilebilir. Öğretmen adayından kaynaklanan zorluklar; ders süresini ayarlayamama (dört öğretmen aday1), sınıf hâkimiyetini sağlayamama (dört öğretmen adayı), duygularını yönetememe (dört öğretmen adayı), etkinliğin fiziki ortama uygun olmaması (üç öğretmen adayı) ve araç-gereç eksikliği (bir öğretmen adayı) şeklinde sınıflandırılmıştır. Öğrencilerden kaynaklanan zorluklar ise; öğrencilerin aktif katılımlarının olmamasından (dört öğretmen adayı) ve öğrencilerin araç-gereç eksikliklerinden (dört öğretmen adayı) kaynaklandığı öğretmen adayları tarafından ifade edilmiştir. Etkinlik uygulama sürecinde yaşanan bu problemlerin bir kısmının adayların etkinlik uygulamaya dair yeterli bilgi ve deneyime sahip olmamalarından, bir kısmının ise adayların etkinlik planlama sürecinde bir takım özellikleri dikkate almamalarından kaynaklandığı söylenebilir. Bu durumla ilgili olarak, etkinlik uygulama sürecine yönelik yapılan araştırma sonuçları (Aykaç, 2007; Aykaç ve Ulubey, 2012; Toptaş, 2008), öğretmenlerin de yeterli bilgi ve donanıma sahip olmadıkları için etkinlik uygulama sürecinde sıkıntı yaşadıklarını göstermektedir. Öte yandan öğretmen adaylarının etkinlik uygulama sürecinde yaşadıkları bu zorlukları aşmak için neler yaptıklarına yönelik görüşlerine bakıldığında; öğretmen adaylarından beşinin etkinlik planında o an için değişiklik yaptığı, ikisinin sınıf hâkimiyetini sağlamak için sık sık sözlü uyarıda bulunduğu ve birer öğretmen adayının ise ödüllendirme uyarısı yapmak zorunda kaldığı, alternatif araç-gereç kullandığı, öğrencilere araç-gereç temin ettiği ve ders sürecini hızlandırdığı görülmüştür. Ayrıca iki öğretmen adayının ise bu süreçte karşılaştığı zorlukları aşmak için elinden bir şey gelmediğini ve çaresiz kaldıklarını ifade ettikleri görülmüştür. Öğretmen adaylarının etkinlik uygulama sürecine dair bu durumları, adayların etkinlik hazırlama, planlama ve uygulama süreciyle ilgili yeterli bilgi ve deneyime sahip olmadıklarını göstermektedir.
Etkinlik uygulama sürecinde öğretmen adaylarının matematiksel terim ve kavramları doğru bir şekilde kullanıp kullanmadıklarına yönelik görüşleri incelendiğinde; üç adayın hata yaptıklarını ve üç adayın hata yapmadıklarını ifade ettikleri görülürken, altı adayın ise hata yapıp yapmadıklarını fark etmedikleri için görüş bildirmedikleri görülmüştür. Oysaki etkinlik uygulama sürecinde yapılan gözlemler değerlendirildiğinde, uygulama sürecinde hata yapmadığını belirten üç adaydan ikisinin bazı matematiksel terim ve kavramları hatalı kullandıkları görülmüştür. Bu konuda görüş belirtmeyen altı adaydan dördünün ise bazı hatalı kullanımlarda bulundukları gözlenmiştir. Etkinlik uygulama sürecine yönelik yapılan gözlemler, öğretmen adaylarının bu hatalı kullanımlarının, etkinlik hazırlama ve planlama sürecinde yeterince hazırlık yapmamalarından, bilgi eksikliklerinden veya adayların heyecanlarından kaynaklandığını göstermektedir. Etkinliklerin, matematiksel dilin (ifade ve sembollerin) kullanımına ve geliştirilmesine yardımcı olması gerektiği (Altun ve Kayapınar, 2011; Baki, 2008; Bell, 1993; Swan, 2008) göz önüne alındığında, etkinlik uygulama sürecinde matematiksel terim ve kavramların doğru kullanılmasının önemi ortaya çıkmaktadır.

Öğretmen adaylarının etkinlik uygulama sürecinde gözlemledikleri öğrenci tutumlarına yönelik görüşleri incelendiğinde; öğretmen adaylarından onunun öğrencilerin istekli ve olumlu tavır takındıklarını, ikisinin ise öğrencilerin isteksiz ve olumsuz tavır sergilediklerini ifade ettikleri görülmüştür. Etkinliklerin öğrenciler üzerinde ve öğrenme-öğretme sürecinde olumlu etkilere neden olduğu (Choo, 2007; Horoks ve Robert, 2007; Jones ve Pepin, 2016; Simon ve Tzur, 2004; Stylianides ve Stylianides, 2008; Sullivan, Clarke ve Clarke, 2013; Watson ve Mason, 2007; Zaslavsky ve Sullivan, 2011) dikkate alındığında ve ayrıca etkinlik uygulama sürecine yönelik gözlemlerden elde edilen bulgular değerlendirildiğinde, etkinlik uygulama sürecinde öğrencilerin isteksiz ve olumsuz tavır takındıklarını ifade eden iki öğretmen adayının bu gözlemlerinin etkinlik uygulama sürecine yönelik bilgi ve deneyim eksikliklerinden kaynaklandığı söylenebilir.

Öğretmen adaylarının etkinlik uygulama süreciyle ilgili kendilerini nasıl değerlendirdiklerine yönelik görüşleri incelendiğinde; öğretmen adaylarından altısının kendilerini yetersiz gördüklerini, birinin kendisini kısmen yetersiz/yeterli gördüğünü ve beş adayın ise kendilerini yeterli gördüklerini ifade ettikleri görülmüştür. Öğretmen adayları tarafindan dile getirilen bu durum, adayların çoğunluğunun etkinlik uygulama sürecine ilişkin yeterli bilgi ve deneyime sahip olmadıklarını ortaya koymaktadır. $\mathrm{Bu}$ konuyla ilgili olarak Uğurel, Bukova-Güzel ve Kula (2010) yaptıkları araştırmada öğretmenlerin de öğrenme etkinliğine ilişkin kendilerini kavrama, anlama, uygulama ve değerlendirme boyutlarında yetersiz gördüklerini ifade etmişlerdir. Yine Aykaç (2007) araştırmasında birçok öğretmenin etkinlikleri uygulama sürecine dair kendilerini yetersiz hissettiklerini belirtmiştir.

Öğretmen adaylarının etkinliklere dayalı bir öğretim sürecinin öğretmenlere sağladığı faydalara yönelik görüşleri incelendiğinde; öğretmen adaylarından onunun etkinliklere dayalı bir öğretim sürecinin öğretmeni derse karşı motive ettiğini, onunun konunun kavratılmasını kolaylaştırdığı için öğretmenin işini kolaylaştırdığını, 
üçünün öğretmenin mesleki gelişimine yardımcı olduğunu ve ikisinin ise öğretmenin yaratıcı düşünme gücünü geliştirdiğini ifade ettikleri görülmüştür. Diğer taraftan ögretmen adaylarının etkinliklere dayalı bir öğretim sürecinin öğrencilere sağladığı faydalara yönelik görüşlerine bakıldığında ise; bütün öğretmen adaylarının etkinliklerin kalıcı öğrenmeyi sağladığı konusunda hemfikir oldukları, beş öğretmen adayının etkinliklerin öğrencilerin derse ilgi duymalarını sağladığını ve bir adayın ise etkinliklerin öğrencilerin bakış açılarını geliştirdiğini belirttikleri görülmüştür.

Etkinliklerin başarıyla sonuçlanması için uygulama öncesinde, yani etkinliğe hazırlık aşamasında; sınıf ortamının etkinlik sürecine uygun olarak düzenlenmesi, öğrencilerin etkinlik için dikkatlerinin çekilmesi ve güdülenmelerinin sağlanması ve etkinliğin amacı ve süresi hakkında öğrencilerin bilgilendirilmesi gibi bazı durumların dikkate alınması gerekmektedir. Öğretmen adaylarının etkinlik uygulama süreçlerine ilişkin yapılan gözlemlerden elde edilen veriler incelendiğinde; iki öğretmen adayının hazırladıkları iki etkinlikte grupla çalışma şeklini tercih etmelerine rağmen, adayların etkinlik uygulamasının hazırlık aşamasında sınıf ortamını etkinliğe uygun olarak düzenlemedikleri gözlenmiştir. Yine etkinliğe hazırlık aşamasında, öğretmen adaylarının uyguladıkları etkinliklerin büyük bir çoğunluğunda, öğrencilerin etkinlik için dikkatlerinin çekilmediği ve güdülenmelerinin sağlanmadığı ve etkinliğin amacı ve süresi hakkında öğrencilerin bilgilendirilmediği görülmüştür. $\mathrm{Bu}$ durum öğretmen adaylarının etkinlik uygulama süreçlerini olumsuz olarak etkilemiştir. Etkinlik uygulama sürecinde plan dişında gelişen bu olumsuz durumlara öğretmen adaylarının genel olarak uygun bir şekilde müdahale edemedikleri gözlenmiştir. Ayrıca öğretmen adaylarının etkinliklerin büyük bir çoğunluğunun sonunda, etkinliğin amac1 doğrultusunda öğrencilerin düşüncelerini ve öğrendiklerini tartışmalarına imkân sağlamalarına firsat vermedikleri görülmüştür. Son olarak daha sonraki uygulamalara yönelik etkinlik üzerinde düzenlemelerin yapılabilmesi adına, öğretmen adaylarının etkinliklerin hiçbirinde öğrencilerin görüşlerini almadıkları gözlenmiştir. Yapılan bu gözlemler araştırma grubundaki öğretmen adaylarının etkinlik uygulama sürecine yönelik yeterli bilgi ve donanıma sahip olmadıklarını göstermektedir.

Araştırmadan elde edilen sonuçlara dayanarak şu önerilere yer verilebilir:

- Öğretmen adaylarının etkinlik uygulama sürecine yönelik deneyim kazanmaları için öğretmenlik uygulaması dersinde adaylara sıklıkla etkinlik içerikli uygulama çalışmaları yaptırılabilir.

- İlköğretim matematik öğretmenliği lisans programında yer alan derslerin içerikleri belirlenirken ortaokul matematik dersi öğretim programının içeriği göz önüne alınarak bu paralelde öğretmen adaylarının etkinlik uygulama sürecine ilişkin becerilerini geliştirmeye yönelik uygulamalı olarak düzenlenebilir.

- Etkinlik uygulama sürecine yönelik etkinlik içerikli, öğretmen adaylarına yol gösteren bilgilendirici kitap vb. kaynaklar hazırlanarak adaylara destek sağlanabilir.

- Etkinlik uygulama sürecine dair farklı örneklemler üzerinde çalışmalar yapılarak etkinlik uygulama sürecinde yaşanabilecek farklı durumların da ele alınması ve bu doğrultuda ögrretmen adaylarına ne gibi katkılar sağlanabileceği üzerine tartışmalar yapılabilir.

\section{Kaynakça}

Altun, M. ve Kayapınar, A. Y. (2011). Lise öğrencilerinin işaret fonksiyonu bilgisini oluşturma süreci. Eğitim ve Bilim, 36(162), 66-83.

Aydoğdu-İskenderoğlu, T. ve Baki, A. (2011). İlköğretim 8. sınıf matematik ders kitabındaki soruların PISA matematik yeterlik düzeylerine göre sınıflandırılması. Eğitim ve Bilim, 36(161), 287-301.

Aykaç, N. (2007). İlköğretim programında yer alan etkinliklerin öğretmen görüşleri doğrultusunda değerlendirilmesi (Sinop ili örneği). Ahi Evran Üniversitesi Kırşehir Ĕgitim Fakültesi Dergisi, 8(2), 19-35.

Aykaç, N. ve Ulubey, Ö. (2012). Öğretmen adaylarının ilköğretim programının uygulanma düzeyine ilişkin görüşleri. Ankara Üniversitesi Eğitim Bilimleri Fakültesi Dergisi, 45(1), 63-82.

Baki, A. (2008). Kuramdan uygulamaya matematik eğitimi (4. Baskı). Ankara: Harf Eğitim Yayıncılık.

Baki, A. ve Hacısalihoğlu-Karadeniz, M. (2013). Okul öncesi eğitim programının matematik uygulama sürecinden yansımalar. Kastamonu Üniversitesi Kastamonu Ĕ̆itim Dergisi, 21(2), 619-636.

Bal, A. P. (2008). Yeni ilköğretim matematik öğretim programının öğretmen görüşleri açısından değerlendirilmesi. Çukurova Üniversitesi Sosyal Bilimler Enstitüsü Dergisi, 17(1), 53-68.

Bell, A. (1993). Principles for the design of teaching. Educational Studies in Mathematics, 24(1), 5-34.

Bogdan, R. C. \& Biklen, S. K. (2007). Qualitative research in education: An introduction to theory and methods (5th ed.). New York: Pearson Publishing.

Choo, C. B. (2007). Activity-based approach to authentic learning in a vocational institute. Educational Media International, 44(3), 185-205.

Christiansen, B. and Walther, G. (1986). Task and activity. In B. Christiansen, A.G. Howson and M. Otte (Eds.), Perspectives on mathematics education (pp. 243307). The Netherlands: Reidel.

Clements, D. H. and McMillen, S. (1996). Rethinking concrete manipulatives. Teaching Children Mathematics, 2(5), 270-279.

Darling-Hammond, L. (2000). How teacher education matters. Journal of Teacher Education, 51(3), 166173.

Doyle, W. (1983). Academic work. Review of Educational Research, 53, 159-199.

Doyle, W. (1988). Work in matehematics classes: The context of students' thinking during instruction. Educational Psychologist, 23(2), 167-180. 
Duru, A. ve Korkmaz, H. (2010). Öğretmenlerin yeni matematik programı hakkındaki görüşleri ve program değişim sürecinde karşılaşılan zorluklar. Hacettepe Üniversitesi Eğitim Fakültesi Dergisi, 38, 67-81.

Elbers, E. (2003). Classroom interaction as reflection: Learning and teaching mathematics in acommunity of inquiry. Educational Studies in Mathematics, 54, 77-99.

Grevholm, B., Milman, R. and Clarke, B. (2009). Function, form and focus: The role of tasks in elementary mathematics teacher education. In B. Clarke, B. Grevholm and R. Millman (Eds.), Tasks in primary mathematics teacher education (pp. 1-5). New York, USA: Springer Science+Business Media, LLC.

Gürbüz, R. ve Toprak, Z. (2014). Aritmetikten cebire geçişi sağlayacak etkinliklerin tasarlanması, uygulanması ve değerlendirilmesi. Necatibey Eğitim Fakültesi Elektronik Fen ve Matematik Eğitimi Dergisi, 8(1), 178-203.

Gürbüz, S. ve Şahin, F. (2014). Sosyal bilimlerde araştırma yöntemleri (1. Bask1). Ankara: Seçkin Yayıncılı.

Hallinan, M. T. and Khmelkov, V. T. (2001). Recent developments in teacher education in the Unated States of America. Journal of Education for Teaching, 27(2), 175-185.

Henningsen, M. and Stein, M. K. (1997). Mathematical tasks and student cognition: Classroom-based factors that support and inhibit high-level mathematical thinking and reasoning. Journal for Research in Mathematics Education, 28(5), 524549.

Herbst, P. (2008). The teacher and the task. The 32nd Annual Meeting of the North American Chapter of the International Group for the Psychology of Mathematics Education. Morelia, Michoacán; Mexico.

Hiebert, J. and Wearne, D. (1993). Insructional tasks, classroom discourse and students' learning in second grade artihmetic. American Educational Research Journal, 30(2), 393-425.

Horoks, J. and Robert, A. (2007). Task designed to highlight task-activity relationships. Journal of Mathematics Teacher Education, 10, 279-287.

Hsu, W. M. (2013). Examining the types of mathematical tasks used to explore the mathematics instruction by elementary school teachers. Creative Education, 4(6), 396-404.

Jones, I. and Pratt, D. (2006). Connecting the equals sign. International Journal Computer for Mathematical Learning, 11(3), 301-325.

Jones, K. and Pepin, B. (2016). Research on mathematics teachers as partners in task design. Journal of Mathematics Teacher Education, 19(2), 105-121.

Karakuş, M. ve Yeşilpınar, M. (2013). İlköğretim altıncı sinıf matematik dersinde uygulanan etkinliklerin ve ölçme-değerlendirme sürecinin incelenmesi: Bir durum çalıșması. Pegem Eğitim ve Öğretim Dergisi, 3(1), 35-54.

Kerpiç, A. (2011). Etkinlik tasarım prensipleri çerçevesinde 7. sinıf matematik ders kitabı etkinliklerinin değerlendirilmesi (Yüksek lisans tezi). Gaziantep Üniversitesi Sosyal Bilimler Enstitüsü, Gaziantep.

Kilpatrick, J., Swafford, J. and Findell, B. (2001). Adding it up: Helping children learn mathematics. Washington, DC: National Academy Press.

McMillan, J. H. and Schumacher, S. (2010). Research in education: evidence-based inquiry (7th ed.). New York: Pearson Publishing.

Milli Eğitim Bakanlığ1 [MEB] (2009). İlköğretim Matematik Dersi 6-8. Sınıflar Öğretim Programı ve Kılavuzu. Ankara.

Mishra, S. K. and Yadav, B. (2013). Effect of activity based approach on achievement in science of students at elementary stage. International Journal of Basic and Applied Science, 1(4), 716-733.

Moyer, P. S. and Jones, M. G. (2004). Controlling choice: Teachers, students and manipulatives in mathematics classrooms. School Science and Mathematics, 104, 16-31.

Özden, Y. (2009). Öğrenme ve öğretme (9.Bask1). Ankara: Pegem Yayınları.

Özgen, K. ve Alkan, H. (2011). Matematik öğretmen adaylarının öğrenme stillerine göre etkinliklere yönelik tercih ve görüşlerinin incelenmesi. Hacettepe Üniversitesi Ĕ̈itim Fakültesi Dergisi, 41, 325-338.

Özgen, K. ve Alkan, H. (2014). Matematik öğretmen adaylarının etkinlik geliştirme becerilerinin incelenmesi. Kuram ve Uygulamada Eğitim Bilimleri, 14(3), 1179-1201.

Özmantar, M. F., Bozkurt, A., Demir, S., Bingölbali, E. ve Açıl, E. (2010). Sınıf öğretmenlerinin etkinlik kavramına ilişkin algıları. Selçuk Üniversitesi Ahmet Keleşoğlu Ĕgitim Fakültesi Dergisi 30, 379-398.

Patton, M. Q. (2002). Qualitative research and evaluation methods (3rd ed.). London: Sage Publications.

Shakirova, L., Falileeva, M. and Kinder, M. (2016). Teaching to solve tasks at mathematics lessons: Teacher's intellectual challenge. The INTED2016 Conference. Valencia; Spain.

Simon, M. A. and Tzur, R. (2004). Explicating the role of mathematical tasks in conceptual learning: An elaboration of the hypothetical learning trajectory. Mathematical Thinking and Learning, 6(2), 91-104.

Stein, M. K. and Smith, M. S. (1998). Mathematical tasks as a framework for reflection: From research to practice. Mathematics Teaching in the Middle School, 3(4), 268-275.

Stein, M. K., Grover, B. W. and Henningsen, M. (1996). Building student capacity for mathematical thinking and reasoning: An analysis of mathematical tasks 
used in reform classrooms. American Educational Research Journal Summer, 33(2), 455-488.

Stein, M. K., Smith, M. S., Henningsen, M. A. and Silver, E. A. (2009). Implementing standards-based mathematics instruction: A casebook for professional development (2nd ed.). New York: Teachers College Press.

Stylianides, A. J. and Stylianides, G. J. (2008). Studying the classroom implementation of tasks: High-level mathematical tasks embedded in 'real-life' contexts. Teaching and Teacher Education, 24(4), 859-875.

Sullivan, P., Clarke, D. and Clarke, B. (2009). Converting mathematics tasks to learning opportunities: An 1mportant aspect of knowledge for mathematics teaching. Mathematics Education Research Journal, 21(1), 85-105.

Sullivan, P., Clarke, D. and Clarke, B. (2013). Teaching with tasks for effective mathematics learning. New York: Springer Science+Business Media.

Sullivan, P., Clarke, D., Clarke, B. and O'Shea, H. (2010). Exploring the relationship between task, teacher actions, and student learning. PNA, 4(4), 133-142.

Swan, M. (2008). Designing multiple representation learning experience in secondary algebra. Journal of International Society for Design and Development in Education, 1(1), 1-17.

Tatsis, K., Kafoussi, S. and Skoumpourdi, C. (2008). Kindergarten children discussing the fairness of probabilistic games: The creation of a primary discursive community. Early Chilhood Education Journal, 36, 221-226.

Toprak, Ç., Uğurel, I. ve Tuncer, G. (2014). Öğretmen adaylarının geliştirdikleri matematik öğrenme etkinliklerinin seçilen konu, amaç, uygulama şekli bileşenleri açısından analizi. Turkish Journal of Computer and Mathematics Education, 5(1), 39-59.

Toptaş, V. (2008). Geometri öğretiminde sınıfta yapılan etkinlikler ile öğretme-öğrenme sürecinin incelenmesi. Illkögretim Online, 7(1), 91-110.
Tzur, R. (2002). From theory of practice: explaining successful and unseccessful teaching activities (Case of frantions) (Tech. Rep. No. 143). USA: North Carolina State University.

Tzur, R., Zaslavsky, O. and Sullivan, P. (2008). Examining teachers' use of (nonroutine) mathematical tasks in classrooms from three complementary perspectives: teacher, teacher educator, researcher. The 32nd Annual Meeting of the North American Chapter of the International Group for the Psychology of Mathematics Education. Morelia, Michoacán; Mexico.

Uğurel, I. ve Bukova-Güzel, E. (2010). Matematiksel öğrenme etkinlikleri üzerine bir araștırma ve kavramsal bir çerçeve önerisi. Hacettepe Üniversitesi Eğitim Fakültesi Dergisi, 39, 333-347.

Uğurel, I., Bukova-Güzel, E. ve Kula, S. (2010). Matematik öğretmenlerinin öğrenme etkinlikleri hakkındaki görüş ve deneyimleri. Buca Eğitim Fakültesi Dergisi, 28, 103-123.

Uşun, S. ve Gökçen, E. (2010). İlköğretim ikinci kademede etkinlik temelli öğretim yaklaşımının öğrencilerin matematik dersine yönelik tutumlarına etkisi. International Online Journal of Educational Sciences, 2(2), 532- 561 .

Watson, A. and Mason, J. (2007). Taken-as-shared: A review of common assumptions about mathematical task in teacher education. Journal of Matmematics Teacher Education, 10(4), 205-215.

Yeniterzi, B. (2009). 7. sinıfta uygulanan rasyonel sayılarla ilgili etkinliklerin matematik kazanımlarını elde etmeye etkisi (Yüksek lisans tezi). Selçuk Üniversitesi Fen Bilimleri Enstitüsü, Konya.

Yin, R. K. (2003). Case study research: Design and methods (3th ed.). London: Sage Publications.

Zaslavsky, O. and Sullivan, P. (2011). Constructing knowledge for teaching secondary mathematics. New York, USA: Springer Science+Business Media, LLC. 